Original Research

\title{
Populasi Buaya Senyulong (Tomistoma schlegelii) di Taman Nasional Tanjung Puting Kabupaten Kotawaringan Barat Kalimantan Tengah
}

\author{
Sosilawaty ${ }^{1,}{ }^{*}$, Mohamad Rizal $^{1}$, Johansyah ${ }^{1}$, Reynol Sainz Situmeang ${ }^{2}$ \\ ${ }^{1}$ Jurusan Kehutanan Fakultas Pertanian Universitas Palangka Raya, Jl.Yos Sudarso, Kode Pos 73111, Palangka Raya \\ ${ }^{2}$ PT. ITCI Hutani Manunggal (IHM), Kalimantan Timur \\ *Korespondensi: Sosilawaty (Email: fapertaupr5@gmail.com)
}

\begin{abstract}
Indonesia known as center of Senyulong Crocodile (Tomistoma schlegelii) habitat in Southeast Asia, beside Sarawak and Peninsula Malaysia, Thailand and Brunei Darussalam. In the country, the crocodile can be found in East Sumatra, Kalimantan, and West Java. This research aims to determine the population and structure of Senyulong Crocodile (Tomistoma schlegelii) in Tanjung Puting National Park in West Kotawaringin District, Central Kalimantan. As the results, as many as 56 individuals of Senyulong Crocodile were found in the Camp Leakey Area (Sekonyer Kanan River) to Muara (Muara Ali) within the park, including 8 adult individuals, 15 individual children, and 33 individual infants. Opportunities for the appearance of one individual in the census (p) are 0,58 with a standard deviation (S) of 3.90. Population density $(\mathrm{N})$ estimated about 16.09 individuals. The average observed individual from each observation $(\overline{\mathrm{x}})$ was 9.33 individuals.
\end{abstract}

Keywords

Population, density, Senyulong Crocodile (Tomistoma schlegelii), Tanjung Puting National Park

\section{PENDAhUluAN}

Indonesia dikenal mempunyai 4 jenis buaya yaitu buaya Senyulong (Tomistoma schlegelii), buaya Muara (Crocodylus porosus), buaya Siam (Crocodylus siamensis), buaya Irian (Crocodylus novaguineae). Keempat jenis buaya tersebut dilindungi berdasarkan Peraturan Menteri Lingkungan Hidup dan Kehutanan Republik Indonesia Nomor P.92/ MENLHK/ SETJEN/KUM.1/8/2018 tentang Perubahan Atas Peraturan Menteri Lingkungan Hidup dan Kehutanan Nomor P.20/MENLHK/SETJEN/KUM.1/6/2018 tentang Jenis Tumbuhan dan Satwa yang Dilindungi. Berdasarkan peraturan tersebut pemanfaatan semua jenis buaya harus mendapat ijin Menteri Lingkungan Hidup dan Kehutanan Indonesia. Dari keempat jenis buaya yang terdapat di Indonesia, hanya 2 jenis buaya yang dapat dimanfaatkan untuk tujuan komersial yaitu buaya Muara (Crocodylus porosus) dan buaya Irian (Crocodylus novaguineae) sedangkan 2 jenis yang tidak komersial yaitu buaya Senyulong (Tomistoma schlegelii) dan buaya Siam (Crocodylus siamensis).
Buaya Senyulong (Tomistoma schlegelii) merupakan salah satu spesies buaya dengan ukuran tubuh yang besar (Stuebing et al., 2006). Panjang tubuhnya dapat mencapai 3,5m tetapi ini sangat jarang sekali ditemukan. Di Indonesia buaya Senyulong merupakan satwa yang dilindungi. Buaya Senyulong memiliki status vulnerable dalam The IUCN Red List of Threatened Species ${ }^{\mathrm{TM}}$. Hal ini berarti buaya Senyulong menghadapi resiko kepunahan yang tinggi di alam liar (IUCN, 2015). Dalam Convention on International Trade in Endangered Spesies of Wild Flora and Fauna (CITES), buaya Senyulong termasuk dalam Appendix 1. Hal ini berarti buaya Senyulong terancam punah dan CITES melarang perdagangan internasional terhadap spesimen spesies ini (CITES, 2015).

Upaya mempertahankan kelestarian buaya Senyulong telah dilakukan, salah satunya di Taman Nasional Tanjung Puting (TNTP). Akan tetapi data tentang jumlah buaya Senyulong di TNTP saat ini masih sangat minim. Padahal informasi tersebut diperlukan dalam rangka perumusan tindakan pelestariannya sehingga ditentukan teknik konservasi yang tepat untuk diterapkan di lapangan. 
Penelitian ini bertujuan untuk mengetahui populasi dan struktur umur buaya Senyulong (Tomistoma schlegelii) di kawasan Taman Nasional Tanjung Puting, Kabupaten Kotawaringin Barat, Kalimantan Tengah.

\section{METODOLOGI}

Penelitian dilakukan di Camp Leakey (Sungai Sekonyer Kanan) sampai Muara (Muara Ali) di Taman Nasional Tanjung Puting, Kabupaten Kotawaringin Barat, Kalimantan Tengah. Waktu pelaksanaan penelitian ini selama \pm 10 bulan mulai dari September 2018 sampai Juli 2019.

Objek yang diamati dalam penelitian ini adalah Buaya Senyulong (Tomistoma schlegelii) yang ditemukan pada lokasi penelitian. Peralatan penelitian yang digunakan terdiri atas GPS, alat tulis, teropong Nikon, jam tangan, kamera Canon, kalkulator, meteran, perahu atau speed boat, komputer, tally sheet, dan lampu sorot tangan dengan bola lampu berukuran $15 \mathrm{~cm}$, dan berkekuatan 12V/100 W di sisi depan.

\subsection{Pengumpulan Data}

Kegiatan pengumpulan data terdiri dari:

1. Pengamatan kepadatan buaya Senyulong dengan menghitungjumlah individu buaya per $1 \mathrm{~km}$ panjang sungai

2. Pengamatan dilakukan dengan mencatat jumlah seluruh individu yang terlihat dari jarak langsung pada jalur-jalur pengamatan terhadap objek buaya Senyulong

3. Pengamatan diulangi selama 6 kali (hari).

\section{2. Pembuatan Jalur Penelitian}

Jalur dibuat dengan metode purposive sampling dan pengambilan data dilakukan dengan metode survei penyorotan. Survei dengan penyorotan menjadikan kepadatan buaya (jumlah individu per kilometer panjang sungai) dapat diketahui. Survei dilakukan dari perahu motor kecil/sampan atau speed boat. Apabila memungkinkan, survei dilakukan pada kondisi surut, sehingga lebih banyak buaya yang dapat dijumpai di pinggir sungai (Messel et al., 1981).

Survei dimulai pada pukul 20.00 WIB sampai pukul 01.00 WIB. Lokasi atau tempat dimulainya dan selesainya survei beserta lokasi-lokasi temuan buaya direkam dengan GPS. Buaya diidentifikasi kedalam spesies atau dicatat sebagai sinar mata jika hanya pantulan sinar mata saja yang terlihat. Panjang buaya ditemukan selama survei dengan penyorotan diperkirakan secara kasar dalam ukuran meter, yang memberikan tingkat keakuratan yang lebih tinggi.

\subsection{Analisis Data}

Populasi buaya Senyulong dari hasil pengamatan dianalisis dengan mengunakan Metode Hanson (Setiadi dan Tjondronegoro, 1989), yaitu:

$$
p=\frac{\bar{X}-S}{\bar{X}}
$$

\section{Keterangan}

$p=$ Peluang terlihatnya satu individu dalam sensus

$\mathrm{S}=$ Standar deviasi

$\bar{X}=$ Rata-rata individu dari seluruh pengamatan

Sementara itu, dugaan besarnya kepadatan populasi buaya Senyulong didekati dengan persamaan Hanon, yaitu:

$$
N=\frac{\bar{X}}{p}
$$

Keterangan:

$\mathrm{N}=$ Kepadatan populasi yang diduga

\section{HASIL DAN PEMBAHASAN}

\subsection{Populasi Buaya Senyulong (Tomistoma schlegelii)}

Pengamatan populasi buaya Senyulong dilakukan dengan menyusuri Sungai Sekonyer Kanan (Camp Leakey) sampai Muara (Muara Ali) menggunakan speed boat sejauh 25,1 km dengan 6 kali pengulangan. Survei dimulai pada pukul 20.00 WIB hingga pukul 01.00 WIB. Hasil pengamatan disajikan pada Tabel 1.

Tabel 1. Hasil pengamatan populasi buaya Senyulong (Tomistoma schlegelii)

\begin{tabular}{ccccc}
\hline \multirow{2}{*}{ Pengulangan } & \multicolumn{3}{c}{ Struktur umur } & \multirow{2}{*}{ Jumlah } \\
\cline { 2 - 4 } & $\mathrm{H}$ & $\mathrm{J}$ & $\mathrm{A}$ & \\
\hline 1 & 14 & 3 & - & 17 \\
2 & 4 & 1 & 4 & 9 \\
3 & 4 & 5 & 2 & 11 \\
4 & 3 & 2 & - & 5 \\
5 & 3 & 3 & 1 & 7 \\
6 & 5 & 1 & 1 & 7 \\
\hline \multicolumn{5}{c}{ Total $\left(\sum\right)=56$} \\
\hline \multicolumn{5}{c}{$\mathrm{Pata}-\mathrm{rata}=9.33$} \\
\hline \multicolumn{5}{c}{$\mathrm{N}=16.09$} \\
\hline
\end{tabular}

Keterangan:

$\mathrm{H}=$ bayi $(<50 \mathrm{~cm})$

$\mathrm{J}=\operatorname{anak}(50-150 \mathrm{~cm})$

$A=\operatorname{dewasa}(>150 \mathrm{~cm})$

Analisis data menunjukkan bahwa rata-rata individu dari seluruh pengamatan adalah 9,33 individu dengan varians (devisiasi) sebesar 3,90. Peluang terlihatnya satu individu dalam pengamatan diperoleh 0,58. Dengan demikian besarnya dugaan kepadatan populasi buaya 
Senyulong sebesar 16,09 individu, dan jika dirata-ratakan maka kepadatan populasi Buaya Senyulong dalam $1 \mathrm{~km}$ adalah 0,64 individu/km.

Pengamatan dan perhitungan jumlah populasi buaya Senyulong di lapangan melalui jalur sungai telihat bahwa populasi buaya Senyulong lebih banyak terdapat di Muara (Muara Ali). Areal tersebut digunakan sebagi tempat berlidung selain itu juga dipergunakan sebagai sumber tempat mencari makanan. Hal ini sesuai dengan pendapat Alikodra (2002) yang menyatakan bahwa komponen habitat yang terpenting untuk kehidupan satwa adalah makanan, air dan tempat berlindung.

Populasi buaya Senyulong nampak lebih sedikit di Camp Leakey (Sungai Sekonyer Kanan) dibandingkan pada Muara Ali (Muara). Pada Camp Leakey (Sungai Sekonyer Kanan) terdapat lebih sedikit tempat berlindung buaya dari bahaya dikarenakan daerah tersebut lebih didominasi oleh pohon Rengas (Gluta renghas) daripada Nipah (Nypa fruticans), Tebu Rawa (Hanguana malayana), dan Rumput Pisau (Pandanus sp). Selain itu di daerah tersebut juga ditujukan sebagai destinasi wisata yang mengakibatkan ancaman bahaya pada buaya Senyulong semakin besar. Sedangkan pada Muara (Muara Ali), karakter tumbuhan masih didominasi oleh Nipah (Nypa fruticans), Tebu Rawa (Hanguana malayana), dan Rumput Pisau (Pandanus sp) dengan ketinggian mencapai 2 meter. Bentuk daun yang panjang, lebar dan berduri serta rapat, memiliki keuntungan tersendiri bagi buaya Senyulong untuk berlindung dari ancaman dan serangan bahaya seperti elang, burung enggang dan musang.

Berdasarkan hasil yang terlihat dari pengamatan di lapangan buaya Senyulong lebih memilih tempat berlindung seperti Nipah (Nypa fruticans), Tebu Rawa (Hanguana malayana) dan Rumput Pisau (Pandanus sp) yang relatif masih banyak terdapat di Muara (Muara Ali) dibandingkan di Camp Leakey (Sungai Sekonyer Kanan).

\subsection{Pola Sebaran Buaya Senyulong (Tomistoma schlegelii)}

Buaya merupakan hewan ectotherms yang artinya mereka bergantung kepada sumber panas dari luar untuk mengatur temperatur tubuhnya. Pada pagi hari ketika sinar matahari sudah mulai muncul, sekitar pukul 07.15, buaya keluar dari dalam sungai menuju ketepian untuk melakukan basking (berjemur). Hal ini dimaksudkan untuk menaikkan suhu tubuhnya sehingga mencapai suhu yang dibutuhkan untuk melakukan kegiatan normal dan untuk mengembalikan kalori yang hilang selama di dalam sungai pada malam harinya. Buaya umumnya membuka mulutnya sampai matahari terik sebagai mekanisme pendinginan untuk menjaga suhu tubuhnya. Kemudian buaya masuk kedalam semak-semak yang lembab atau kembali ke sungai dengan kondisi setengah tubuhnya terendam. Buaya di alam bersifat secretive (suka bersembunyi) dan jarang terlihat dalam kelompok. Pada sore hari buaya keluar untuk mencari makan dan pada malam hari turun ke sungai (berendam di dalam air) karena suhu air lebih tinggi (hangat) daripada di darat (Whitaker, dalam Harto, 2002).
Bentuk Pola Sebaran buaya Senyulong di Camp Leakey (Sungai Sekonyer Kanan) sampai Muara (Muara Ali) memiliki bentuk sebaran yang mengelompok. Kecenderungan hidup mengelompok ini berarti ketika kita menemukan satu individu buaya Senyulong di suatu bagian Camp Leakey (Sungai Sekonyer Kanan) sampai Muara (Ali), kemungkinan individu yang lainnya juga terdapat tidak jauh dari tempat individu yang pertama ditemukan. Bentuk sebaran buaya Senyulong ini dipengaruhi oleh faktor ketersediaan makanan dan tingkat gangguan manusia. Buaya Senyulong mengelompok pada Camp Leakey (Sungai Sekonyer Kanan) dan Muara (Muara Ali). Hal ini dikarenakan pada Muara (Muara Ali) masih banyak di tumbuhi Nipah (Nypa fruticans) Tebu Rawa (Hanguana malayana) dan Rumput Pisau (Pandanus sp), sehingga memiliki keuntungan untuk berlindung dari ancaman dan serangan bahaya seperti elang, burung enggang dan musang.

\subsection{Ukuran Populasi Buaya Senyulong (Tomistoma schlegelii)}

Kartono dan Santosa (1995) menyatakan bahwa ukuran populasi satwa liar dapat memberikan informasi mengenai nilai rata-rata, nilai minimum dan nilai maksimum dari jumlah individu di dalam satu populasi jenis satwa liar tertentu. Nilai minimum merupakan jumlah individu terendah/terkecil pada suatu populasi ataupun dalam satu kelompok, sedangkan nilai maksimum merupakan jumlah individu tertingi/terbesar pada suatu populasi ataupun dalam yang ditemukan selama penelitian atau pengamatan.

Jumlah populasi buaya Senyulong di Camp Leakey (Sungai Sekonyer Kanan) sampai Muara Ali (Muara) selama 6 kali diperoleh nilai minimum sebesar 5 individu dan nilai maksimum sebesar 17 individu. Jumlah buaya Senyulong pada pengulangan ke- 1 sampai ke- 6 yaitu, 17 individu, 9 individu, 11 individu, 5 individu, 7 individu, dan 7 individu. Hal yang menyebabkan pada pengulangan ke-1 sampai ke -3 lebih banyak ditemukan jumlah buaya Senyulong yaitu karena faktor pengunjung yang sedikit sehinga buaya Senyulong pada malam hari lebih banyak keluar untuk mencari mangsa atau makanan. Sedangkan pada pengulangan ke-4 sampai ke- 6 pengunjung lebih banyak sehingga jumlah buaya Senyulong lebih sedikit ditemukan karena pengaruh transportasi pengunjung pada air sehingga Buaya Senyulong dan mangsanya lebih sulit untuk naik ke permukaan.

Jumlah individu 56 individu di Camp Leakey (Sungai Sekonyer Kanan) sampai Muara Ali (Muara). Ini menunjukan bahwa buaya Senyulong hidup relatif sedikit. Auliya et al. (2009) mengemukakan bahwa di Camp Leakey (Sungai Sekonyer Kanan) terdapat 38 individu buaya Senyulong. Sedangkan berdasarkan pengamatan yang dilakukan di lapangan, terdapat penurunan jumlah individu mulai Camp Leakey (Sungai Sekonyer Kanan) sampai Muara Ali (Muara), dengan dugaan kepadatan sebesar 16,09 individu (Tabel 2). Hal ini diakibatkan kurangnya 
Tabel 2. Parameter populasi buaya Senyulong (Tomistoma schlegelii) di Camp Leakey (Sungai Sekonnyer Kanan) sampai Muara Ali (Muara)

\begin{tabular}{lr}
\hline \multicolumn{1}{c}{ Parameter } & Nilai \\
\hline Total individu & 56.00 \\
Rata-rata individu & 9.33 \\
Peluang terlihatnya individu & 0.58 \\
Dugaan kepadatan individu & 16.09 \\
\hline
\end{tabular}

tempat berlindung dari ancaman dan serangan bahaya, dimana pada bayi dan anak-anak buaya yang baru menetas biasanya dimangsa oleh elang, burung enggang, musang, tikus dan kura air tawar. Elang dapat membawa bayi dan anak-anak buaya yang berukuran $82 \mathrm{~cm}$ tanpa mengalami kesulitan (Grzimek, 1975).

\subsection{Komposisi Umur}

Berdasarkan hasil penelitian maka komposisi umur dewasa, anak-anak dan bayi dari buaya Senyulong di lokasi penelitianadalah sebagai berikut:

- Buaya Senyulong dewasa $=8$ individu $=14,29 \%$

- Buaya Senyulong anak-anak = 15 individu $=26,77 \%$

- Buaya Senyulong bayi $=33$ individu $=58,93 \%$

Komposisi umur buaya Senyulong dewasa, anak, dan bayi didominasi oleh buaya Senyulong bayi sehingga populasinya dikatakan tidak jenuh. Menurut Odum (1996), populasi yang sedang berkembang cepat biasanya didominasi oleh individu-individu bayi dan anak-anak, sedangkan populasi yang stationer (statis) pembagian kelas umur yang merata dan populasi yang jenuh sebagian besar terdiri dari kelompok individu sebagian besar terdiri dari kelompok individu yang berumur tua.

\subsection{Struktur Umur}

Struktur umur adalah perbandingan jumlah individu didalam setiap kelas umur dari satu populasi. Struktur umur dapat dipergunakan untuk menilai keberhasilan perkembiakan satwa liar, sehingga dapat dipergunakan pula untuk menilai prospek kelestarian satwa liar (Alikodra, 2002). Struktur umur buaya Senyulong di lokasi penelitian dapat digolongkan sebagai struktur umur yang mengalami peningkatan, yaitu struktur umur yang memiliki kerapatan kecil pada kelas-kelas umur dewasa dan anak, paling besar kerapatan populasinya pada kelas bayi.

Perkembangan populasi ini terus meningkat dan jika keadaan lingkungan berubah, maka dikhawatirkan akan terjadi kepunahan terhadap populasi buaya Senyulong yang ada sekarang ini setelah beberapa tahun yang akan datang. Kenyataan ini dapat dilihat dari struktur umur buaya Senyulong dengan lebih banyaknya jumlah individu bayi 58,93\% dibandingkan anak $26,77 \%$ dan dewasa $14,20 \%$. Bentuk fisik individu buaya disajikan pada Gambar 1.
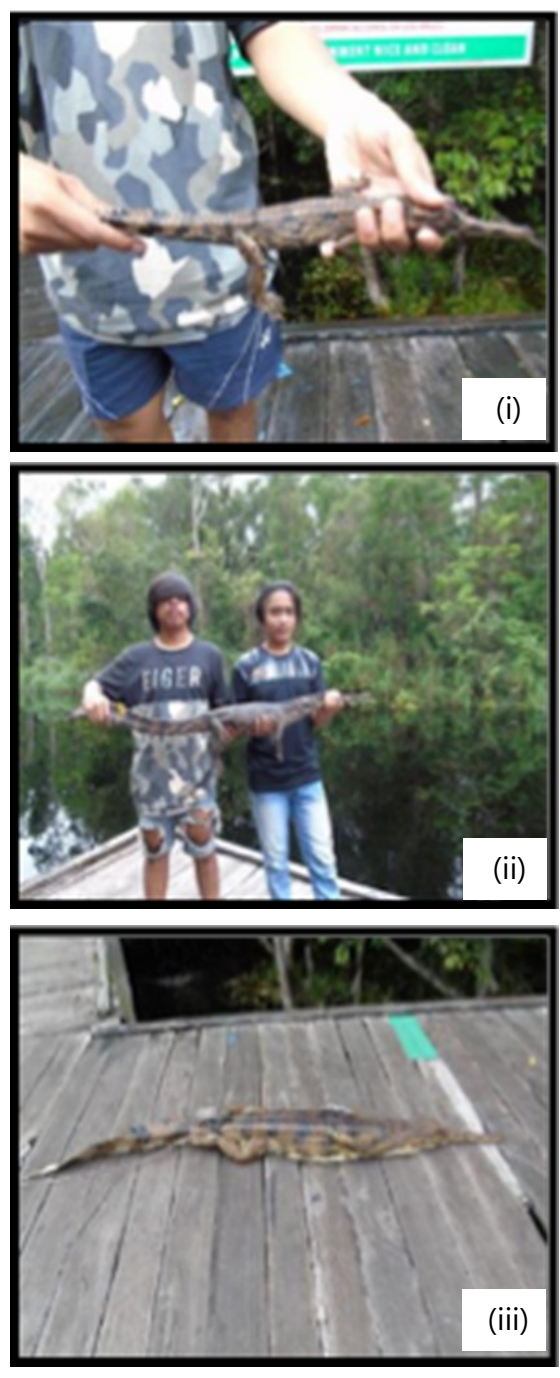

Gambar 1. Bentuk fisik individu buaya. (i) bayi buaya, (ii) anak buaya, (iii) buaya dewasa

Peningkatan struktur umur akibat terjadinya peningkatan reproduksi. Peningkatan reproduksi itu sendiri bisa disebabkan oleh beberapa hal, yaitu:

1. Tempat Berlindung

Buaya merupakan satwa yang tempat hidupnya sebagian besar di air. Jika siang hari buaya berjemur di tepian sungai, di tempat terbuka. Ketika hari mulai gelap sampai sebelum fajar, buaya mulai aktif mencari makan karena buaya merupakan satwa nokturnal yaitu satwa yang aktif di malam hari. Untuk melakukan semua aktivitasnya, buaya memerlukan suatu tempat berlindung. Tempat berlindung yang dibutuhkan biasanya disesuaikan dengan perilaku satwa. Menurut Alikodra (2002), tempat berlindung memiliki fungsi sebagai tempat hidup, berkembang biak dan berlindung dari bahaya, bahkan dapat pula sebagai tempat mencari makan. Jenis vegetasi disekitar lokasi penelitian, yaitu di Camp Leakey (Sungai Sekonyer Kanan) sampai Muara Ali (Muara) didominasi oleh tumbuhan rawa, yaitu Nipah (Nypa fruticans), Tebu Rawa (Hanguana malayana) dan Rumput Pisau 
(Pandanus sp) dengan ketinggian mencapai 2 meter. Kedua jenis tumbuhan tersebut memiliki umbi dan terapung diatas air membentuk suatu daratan terapung. Selain itu terdapat juga vegetasi Rengas (Gluta renghas), Pulai (Alstonia scholaris), Eceng Gondok (Eichhornia crassipes) dan Paku-pakuan yang hidup dan tumbuh menumpang diatas umbi Tebu Rawa (Hanguana malayana) dan Rumput Pisau (Pandanus $s p$ ). Vegetasi yang ada disekitar Camp Leakey (Sungai Sekonyer Kanan) sampai Muara (Muara Ali) ini dimanfaatkan oleh buaya Senyulong untuk membuat sarang, mencari makan, dan tempat berlindung dari bahaya. Vegetasi tempat ditemukannya buaya Senyulong disajikan pada Gambar 2.
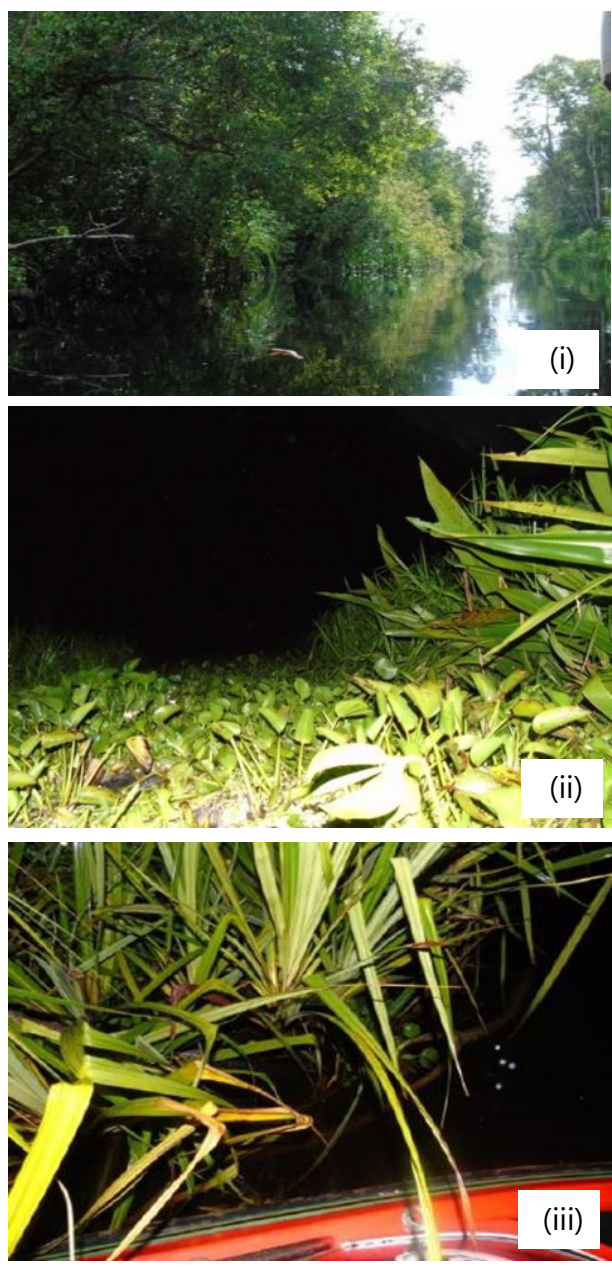

Gambar 2. Vegetasi habitat buaya Senyulong. (i) Rengas (Gluta renghas) dan Pulai (Alstonia scholaris), (ii) Rumput Pisau (Pandanus sp), (iii) Eceng Gondok (Eichhornia crassipes) dan Tebu Rawa (Hanguana malayana).

2. Perairan

Menurut Alikodra (2002), satwa liar mempunyai tingkat adaptasi yang berbeda-beda terhadap ketersediaan air. Berdasarkan segi ketergantungan terhadap air, buaya termasuk ke dalam golongan binatang air yaitu satwa liar yang hidup di dalam air atau di dekat air. Buaya merupakan satwa reptil yang menggunakan perairan sebagai tempat hidup dan berkembang biak. Buaya menggunakan perairan untuk mencari makan, berlindung dari gangguan, dan untuk menyesuaikan suhu tubuh pada malam hari.

Sifat fisik dan kimia perairan sangat berpengaruh terhadap jenis flora dan fauna yang hidup di dalam air. Faktor-faktor perairan yang berpengaruh antara lain adalah tipe sungai, arus, kedalaman, kecerahan, suhu, $\mathrm{pH}$, warna air, kadar gas terlarut dan kadar unsur-unsur terlarut dalam air (Sumawidjaja, 1977). Sehingga faktorfaktor yang dapat diketahui saat penelitian ini yaitu:

a. Kualitas Air

1) Suhu

Suhu air pada Sungai Sekonyer Kanan (Camp Leakey) sampai Muara (Muara Ali) pada saat penelitian diketahui sebesar $23-25^{\circ} \mathrm{C}$. Suhu merupakan faktor lingkungan yang sering kali beroperasi sebagai faktor pembatas. Suhu juga mempengaruhi termoregulasi tubuh buaya Senyulong dalam lingkungan yang berbeda. Suhu juga mempengaruhi aktivitas reproduksi buaya Senyulong. Organisme perairan seperti buaya Senyulong mampu hidup baik pada kisaran suhu $20-30^{\circ} \mathrm{C}$. Perubahan suhu dibawah $20^{\circ} \mathrm{C}$ atau diatas $30^{\circ} \mathrm{C}$ menyebabkan Buaya Senyulong mengalami stres yang biasanya diikuti oleh menurunnya daya cerna (Dirjen PHPA, 1996)

2) $\mathrm{pH}$ Air

Keberadaan Individu buaya Senyulong di sungai Sekonyer Kanan (Camp Leakey) sampai Muara Ali (Muara) itu sendiri menunjukkan bahwa perairan tersebut masih cocok untuk tempat hidup mereka. Fluktuasi $\mathrm{pH}$ berada pada $\mathrm{pH}$ perairan produktif dan ideal bagi satwa air yang ada di Sungai tersebut, yaitu antara 6,5-8,5 (Ricker, 1973).

b. Kondisi Fisik

1) Kedalaman Sungai

Sungai Sekonyer Kanan (Camp Leakey) sampai Muara Ali (Muara) memiliki kedalaman antara $215 \mathrm{~cm}$ sampai $224 \mathrm{~cm}$. Kedalaman 215-224 cm terdapat pada bagian tepi/sisi Sungai Sekonyer Kanan (Camp Leakey) Sampai Muara Ali (Muara), dekat dengan tempat berjemur. Kedalaman yang $\leq 400 \mathrm{~cm}$ ini dimanfaatkan buaya untuk mencari makan karena pada bagian atas perairannya terdapat akar tebu rawa dan rumput pisau yang merupakan tempat mijah udang dan ikan mencari makan. Sedangkan kedalaman lebih dari $400 \mathrm{~cm}$, biasa dimanfaatkan buaya sebagai tempat berlari atau bersembunyi/berlindung dari bahaya dan ancaman. Dimana adanya perburuan oleh manusia, kerusakan habitat akibat eksploitasi hutan, ramainya lalu lintas sungai, pencemaran air dan tekanan penduduk (Anonim, 1976). 
2) Arus Air

Buaya Senyulong hidup di tipe perairan tergenang atau standing water (Lentic). Warna Air kebiruan karena terdapat ganggang atau Lumut di bagian dasar sungai, yang dijadikan sebagai tempat bermain dan mencari makan bagi ikan dan satwa air lainnya yang merupakan satwa mangsa buaya Senyulong. Buaya Senyulong tidak dapat hidup pada perairan yang terpengaruh air pasang/air laut yang bersifat basa (Dirjen PHPA, 1996).

3) Kecerahan Air

Kecerahan air memiliki korelasi yang sejalan dengan tingkat pencemaran air. Air yang tercemar akan memiliki kecerahan yang kecil karena mengandung banyak zat terlarut sehingga air menjadi lebih gelap. Sedangkan air yang masih baik akan memiliki tingkat kecerahan air yang tinggi (Dirjen PHPA, 1996). Sungai Sekonyer Kanan (Camp Leakey) memiliki kecerahan yang tinggi karena air di sana berwarna biru jernih, sehingga bisa dilihat sampai permukaan dasar sungai. Kecerahan air yang rendah terdapat dibagian Muara Ali (Muara) dengan lumut berukuran tinggi.

\section{Potensi/Ketersediaan Makanan}

Buaya merupakan satwa karnivora yang tidak memilihmilih mangsanya. Buaya juga merupakan pemangsa oportunistik, yaitu satwa yang memangsa satwa mangsanya dengan mencari kesempatan disaat satwa mangsanya lengah. Jenis makanannya sangat bervariasi, mulai ikan dan vertebrata kecil. Anakan yang baru menetas biasanya memangsa insekta atau serangga, walaupun beberapa spesies di beberapa habitat memiliki spesialisasi makanan seperti kepiting, udang dan ikan kecil (Dirjen PHPA, 1996).

Ketersediaan makanan, buaya Senyulong di Camp Leakey (Sungai Sekonyer Kanan) sampai Muara Ali (Muara) memiliki makanan yang bisa dikatakan melimpah. Jenis satwa yang bisa dijadikan makanan (mangsa) oleh buaya Senyulong berupa udang, ikan, burung, monyet dan bekantan. Menurut Neil dalam Harto (2002), makanan anak buaya terdiri dari serangga dan ikan. Tumbuh semakin besar makanan buaya meningkat ke ikan besar, burung, ular, monyet dan mamalia lain serta bahkan manusia. Buaya Senyulong memiliki makanan utama berupa ikan, burung, monyet ekor panjang dan bekantan. Di Camp Leakey (Sungai Sekonyer Kanan) sampai Muara Ali (Muara) terdapat banyak ikan karena memiliki habitat yang cocok untuk berkembang biak ikan. Tebu rawa (Hanguana malayana) dan Rumput Pisau (Pandanus sp) memiliki perakaran yang lebat pada umbinya dan biasa digunakan sebagai tempat mijah udang batu (udang hitam) serta ikan-ikan kecil. Dengan intensitas cahaya matahari yang melimpah, di Camp Leakey (Sungai Sekonyer Kanan) sampai Muara Ali (Muara) juga terdapat beberapa jenis lumut yang indah dan biasa digunakan ikan sebagai tempat bermain dan mencari makan. Sehingga ketersediaan makanan bagi buaya Senyulong di Camp Leakey sampai Muara Ali (Muara) bisa dikatakan masih melimpah.

penelitian Ikan Seluang (Rasbora), Ikan Gabus (ChannaSelama striata), Ikan Toman (Channa micropeltes), Bekantan (Narsalis larvatus), Monyet Ekor Panjang (Macaca fascicularis), dan Burung Raja Udang Biru Langit (Alcedo coerulescens) merupakan jenis satwa mangsa buaya Senyulong yang sering di jumpai. Hal ini menunjukkan bahwa ketersediaan makanan atau satwa mangsa memiliki korelasi dengan keberadaan dan persebaran buaya Senyulong pada tiap bagian sungai di Camp Leakey (Sungai Sekonyer Kanan) sampai Muara Ali (Muara). Buaya Senyulong membuat sarang dekat dengan sumber makanan agar ketika bertelur tidak terlalu jauh dari sarang sehingga dapat terus menjaga sarangnya. buaya Senyulong cenderung untuk membuat sarang dekat dengan sumber makanannya.

\section{KESIMPULAN DAN SARAN}

Populasi buaya Senyulong (Tomistoma schlegelii) di Taman Nasional Tanjung Puting diduga memiliki kepadatan populasi sebesar 16,09 individu. Sehingga jika dirataratakan terdapat 0,64 individu/km di sepanjang súngai yang diamati. Struktur umur buaya Senyulong terdiri dari individu bayi sebesar 58,93\%, anak-anak 26,77\%, dan dewasa $14,20 \%$ dengan struktur umur berkembang. Dengan kepadatan populasi dan struktur umur bayi yang tinggi di simpulkan bahwa perkembangan populasi cukup memadai untuk kelangsungan kelestarian buaya di TNTP dengan tetap menjaga habitat tempat hidup buaya.

\section{DAFTAR PUSTAKA}

[Dirjen PHPA] Direktorat Jenderal Perlindungan Hutan dan Pelestarian Alam, Departemen Kehutanan. 1996. Pedoman Inventarisasi Reptil. Bogor: Proyek Pengembangan, Pengelolaan dan Pengamanan Kawasan Konservasi Pusat Tahun Anggaran 1995/1996. Dirjen PHKA.

Alikodra, H.S., 2002. Pengelolaan Satwa Liar Jilid I. Institut Pertanian Bogor. Bogor.

Anonim. 1976. Studi Habitat dan Kemungkinan Pengembangan Populasi Buaya di DAS Lalan Palembang. Bogor: Direktorat Perlindungan dan Pengawetan Alam.

Auliya, M., Schwedick, B., Sommerlad, R. and Brend, S., 2009. A short-term assessment of the conservation status of Tomistoma schlegelii (Crocodylia: Crocodylidae) in Tanjung Puting National Park (Central Kalimantan, Indonesia). In Cooperative Survey by the Orangutan 
Foundation (UK) and the Tomistoma Task Force of the IUCN/SSC Crocodile Specialist Group.

Balai TNTP. 2018. Guide Book Infomasi Keadaan Umum Taman Nasional Tanjung Puting. Pangkalan Bun: Balai Taman Nasional Tanjung Puting.

Bezuijen, M R , Shwedick, B , Simpson, B K , Staniewicz, A , Stuebing, R., 2014. Tomistoma schlegelii. The IUCN Red List of Threatened Species 2014. Diakses 16 April 16 2020 dari http://dx.doi.org/10.2305.IUCN.UK.20141. RLTS.T21981A2780 499.en.

CITES. 2015. Protected Species. Diakses Agustus 2015 dari www.cites.org.

Grzimek, B., 1975. Animal Life Encyclopedia. Volume ke-6, Reptilia. London : Van Nostrand Reinhold Company

Harto, J., 2002. Budidaya dan Pelestarian Buaya Air Tawar Irian (Crocodylus novaeguineae) [Skripsi]. Bogor: Fakultas Kedokteran Hewan. Institut Pertanian Bogor.

IUCN. 2014. IUCN Red List of Threatened Species. Diakses Agustus 2019 dari www.redlist.org.

IUCN. 2015. IUCN Red List of Threatened Species: Tomistoma schlegelii. http://www.iucnredlist.org/ details/12551/0. Diakses pada 1 April 2019.

Kartono, A. P. \& Santosa, Y., 1995. Teknik Pengukuran Dan Monotoring Keanekaragaman Satwa Liar. Skripsi Jurusan Konservasi Sumber Daya Hutan Fakultas Kehutanan Institut Pertanian Bogor, Bogor

Kementerian Kehutanan. 2013. Taman Nasional. Diakses 15 Agustus 2019 dari www.menlhk.go.id.
Messel, H., Vorlicek, G.C., Wells, A.G. \& Green, W.J. 1981. Surveys of Tidal River Systems in the Northern Territory of Australia and Their Crocodile Populations. Monograph 1. Pergamon Press, Sydney.

Odum, E. P., 1996. Dasar-dasar Ekologi. Gajah Mada University Press. Yogyakarta.

Peraturan Menteri Lingkungan Hidup dan Kehutanan Nomor P.20/Menlhk/Setjen/Kum.1/6/2018 tentang Jenis Tumbuhan dan Satwa yang Dilindungi.

Ricker, W.E., 1973. Linear regressions in fishery research. Journal of the fisheries board of Canada, 30(3), 409-434.

Setiadi, D. \& Tjondronegoro, P. D.,1989. Dasar-dasar Ekologi. Depdikbud Ditjen PT. PAUIHIPB.P 138

SK Menteri Kehutanan No. 687/Kpts-II/1996 tanggal 25 Oktober 1996, tentang Perubahan fungsi dan penunjukan Kawasan Hutan yang terletak di Kabupaten Daerah Tk. II Kotawaringin Barat dan Kabupaten Daerah Tk. Il Kotawaringin Timur, Propinsi Kalimantan Tengah seluas $415.040 \mathrm{Ha}$ menjadi Taman Nasional dengan nama Taman Nasional Tanjung Puting.

Stuebing, R.B., Bezuijen, M.R., Auliya, M. and Voris, H.K., 2006. The current and historic distribution of Tomistoma schlegelii (the False Gharial)(Müller, 1838) (Crocodylia, Reptilia). The Raffles Bulletin of Zoology, 54 (1), 181-197.

Sumawidjaja, K., 1977. Limnologi. Fakultas Perikanan Institut Pertanian Bogor. Bogor. 